\title{
Distribution and abundance of the land snail Pollicaria elephas (Gastropoda: Pupinidae) in limestone habitats in Perak, Malaysia
}

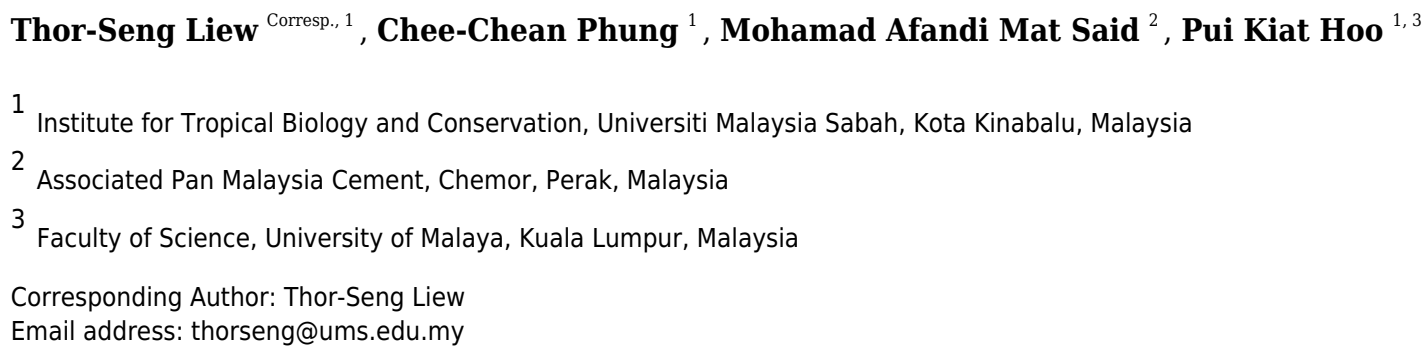

This study aimed to reveal the habitat variables that determine the distribution and abundance of the land snail Pollicaria elephas in limestone habitats in Perak, Malaysia. Seventeen plots were selected on a limestone hill to determine the effect of environmental variables on the abundance of this land snail. The environmental variables we considered included habitat (canopy cover and leaf litter thickness), topography (elevation, aspect, ruggedness, and slope), microclimate (soil temperature, air temperature, and humidity), and vegetation (abundance of respective vascular plant species). The correlation analyses suggested that the snails' abundance was positively correlated with the abundance of the four vascular plant species : Diospyros toposia var. toposoides, Croton cascarilloides, Kibatalia laurifolia, and Mallotus peltatus. Plots with lower soil temperatures had more snails than plots with higher soil temperatures. Our results show that plots in the southern part of the limestone hill, in which P. elephas were absent, were similar in habitat, topography, microclimate, and vegetation to the plots in the northern part of the limestone hill, where specimens were mostly present. The absence of this species in suitable habitats may be due to their low dispersal ability rather than adverse environmental conditions. 
1 Distribution and abundance of the land snail Pollicaria 2 elephas (Gastropoda: Pupinidae) in limestone habitats in 3 Perak, Malaysia

Thor-Seng Liew Corresp.,1, Chee-Chean Phung ${ }^{1}$, Mohamad Afandi Mat Said ${ }^{2}$, Pui Kiat $\mathrm{Hoo}^{3}$

${ }^{1}$ Institute for Tropical Biology and Conservation, Universiti Malaysia Sabah, Malaysia

${ }^{2}$ Associated Pan Malaysia Cement, Perak, Malaysia

${ }^{3}$ Faculty of Science, University of Malaya, Malaysia

Corresponding Author: Thor-Seng Liew

Email address: thorseng@ums.edu.my 
40

41

42

43

44

45

46

47

48

49

50

51

52

53

54

55

56

57

58

59

60

61

62

63

64

65

66

67

68

69

70

71

72

73

74

75

76

\section{Introduction}

There are approximately 1,000 recognised land snail species in Malaysia (http://malaypeninsularsnail.myspecies.info/, $\quad$ http://opisthostoma.myspecies.info/, http://borneanlandsnails.myspecies.info/). However, the ecology of the land snail species is often poorly known. To date, only a handful species from the genera Plectostoma, Georissa, Gyliotrachela, Diplommatina have been studied in terms of their growth (Berry, 1962, 1963; Liew et al., 2014b), reproduction (Berry, 1965), and demography (Berry, 1966; Schilthuizen et al., 2003).

Land snails of the genus Pollicaria, commonly known as elephant pupinid snails, belong to the family Pupinidae. All seven Pollicaria species and subspecies from Indochina and Peninsular Malaysia are endemic to this region. P. elephas is the only Pollicaria species found on Peninsular Malaysia (Kongim et al., 2013) (Fig. 1A). This species was described by de Morgan (1885) in the state of Perak, Malaysia. P. elephas specimens were recorded in various localities from the limestone hills in Perak and from two other locations in Pahang (Chan, 1998; Kongim et al., 2013; Foon et al., 2017; Minton et al., 2017; GBIF.org, 2018).

Some aspects of $P$. elephas' morphology, taxonomy, karyotypes, and geographical distribution have been studied (Pain, 1974; Chan, 1997; Kongim et al., 2010; Kongim et al., 2013). However, the ecology and small-scale distribution of this ground-dwelling species remain unknown. We found localities with very high densities of $P$. elephas during a preliminary survey of a limestone hill in Perak, while just tens of meters away, no snails were found. This patchy distribution is not unusual. A previous study on another similarly-sized land snail, Limicolaria martensiana, also showed an uneven distribution with more than 100 individuals per $\mathrm{m}^{2}$ at one locality at Uganda (Owen, 1969).

Studies of other macro snails from other regions show that a higher land snail abundance can be explained by vegetation or habitat characteristics, such as a denser and heterogeneous canopy and understory, higher litter humidity and thickness, older and bigger trees, rotten logs, and calcium availability (Boag, 1985; Martin and Sommer, 2004; Müller et al., 2005; Horsák et al., 2007; Dvořáková and Horsák, 2012). The flora composition can be difficult to measure directly but may be a very useful predictor for snail communities (Dvořáková and Horsák, 2012).

We examined specific environmental parameters that may be responsible for the unevent distribution of $P$. elephas on a limestone hill. To date, the limestone hill in Perak is the only location where a sizeable living population of $P$. elephas is found based on several systematic samplings of land snails throughout limestone hills in Peninsular Malaysia (Chan, 1997; Clements et al., 2008; Foon et al., 2017). We first assessed the population size and density of P. elephas at different localities on the hill in Perak. We then examined the vegetation and topographic and microclimatic variables for each locality to characterise species-specific requirements.

Peer) reviewing PDF | (2020:09:53097:3:0:NEW 5 Jul 2021) 
77 Materials and Methods

78

79

80

81

82

83

84

85

\section{Study Site}

The study site was located on a limestone hill in Perak, Malaysia. We established a total of 17 plots, each measuring $2 \mathrm{~m} \mathrm{x} 4 \mathrm{~m}$. Seven plots were located in the northern part, nine at the southern part, and one at the central part of the hill (Fig. 2). Each plot was located next to limestone rock outcrops. A pilot survey was conducted to ensure that these plots covered habitats with different environmental variables and to identify plots with living $P$. elephas suitable for the population density study. In each plot, leaf litter was searched manually by two people for over 20 minutes to find living snails and empty shells. Environmental variables for each of the 17 plots were measured during the pilot survey on 11 May 2018.

\section{Spatial distribution and population density}

We did not find any living P. elephas or empty shells in the 11 of the 17 examined plots during the pilot survey (Table 1 in Supplemental File 1). We used the capture-mark-recapture method (CMR) to study the population of P. elephas in five of the six plots with living snails. One of the plots (AP-0) was inaccessible after the pilot survey so the CMR study could not be conducted in that plot. The captured P. elephas were marked with different colours of nail polish (Fig. 1B and 1C) during different sampling sessions. The snails were then released back to their respective plots, and plots were resampled after 10 to 15 days. The CMR was conducted four times for all plots with the exception of one plot (AP-2), where only three CMR sessions took place. The first sampling was conducted on 9 July 2018 and the first recapture was on 19 July 2018, the second recapture occurred on 1 August 2018, and the third recapture took place on 16 August 2018. The collected snails from the following demographics were examined: juvenile ( $<3$ whorls), subadult ( $3-5$ whorls), and adult (with aperture lip). All living snails caught were released back to their respective plots while the empty shells were collected and deposited in the BORNEENSIS collection of Universiti Malaysia Sabah.

We calculated the $P$. elephas population density by counting the living snails in individual plots during the different CMR sessions. The population size of $P$. elephas was estimated based on the data collected using the Schnabel index:

- $\mathrm{N}=$ total number of snails (unknown)

- $\mathrm{C}=$ number of snails captured on the first sampling

- $\mathrm{M}=$ number of snails captured on subsequent sampling

- $\mathrm{R}=$ number of snails captured on both samplings

Multiple marks and recaptures ensured a more accurate estimation of the population size. The Schnabel method (Alcoy, 2013), which allows multiple capture-recapture encounters, was used: 


$$
N=\frac{\sum_{i=1}^{m} M_{i} C_{i}}{\sum_{i=1}^{m} R_{i}}
$$

$M_{i}=$ Total number of previously marked snails at time $i$

$C_{i}=$ The number caught at time $i$

$R_{i}=$ The number of marked snails caught at time $i$

\section{Environmental variables}

We studied four main environmental variables, namely habitat, topography, microclimate, and vegetation. All of the variables were measured for all 17 plots, with the exception of the microclimate. We measured leaf litter thickness by averaging litter thickness at eight points within each plot for habitat variables and estimated the percentage of canopy cover. To obtain topographic variables, we created a digital elevation model (DEM) of $4 \mathrm{~m}^{2}$ cell-size based on a 5 -meter interval contour map for each of the northern and the southern study site using Triangular interpolation (TIN) in QGIS (ver. 2.18.24; QGIS Development Team, 2018). We then used terrain analysis tools to derive topographic features including slope, aspect, and the terrain ruggedness index (a quantitative measurement of terrain heterogeneity) (Riley et al., 1999). Topographic parameters were extracted for each sampling plot using the 'Add raster values to point' setting in SAGA (Conrad et al., 2015).

\section{Microclimatic variables}

We installed climatic HOBO data loggers to record air temperature and humidity (HOBO MX2301 Temperature/RH) approximately one meter above the ground for eight of the 17 plots (A-Polli3, A-Polli9, D-P1, D-P3, D-P8, D-P9, D-P11, D-P12). We recorded the soil temperature using HOBO MX2303 temperature sensors for the same eight plots. External sensors were fully covered by leaf litter. These eight plots have been chosen, as they represent localities with both absence and presence data and different population densities of these snails. Living specimens were found in two northern plots, namely, plot A-Polli9, which had a higher number of snails (15-16 individuals) and plot A-Polli3, which had a lower number of snails (1-2 individuals). There were no living specimens found in the five southern plots. The climatic parameters were logged every 10 minutes in July 2018. Data from the two soil temperature loggers could not be retrieved due to damage by rain and wildlife. 
142

143

144

145

146

147

148

149

150

151

152

153

154

155

156

157

158

159

160

161

162

163

164

165

166

167

168

169

170

171

172

173

174

175

176

177 Results

178 Spatial distribution and population density of the snails

\section{Vegetation data}

We counted and identified all the vascular plants with diameter at breast height (DBH) above 1 $\mathrm{cm}$ within a 5-meter radius from the centre of each of the 17 plots to obtain the number of vascular plant individuals and the number of vascular plant species of each plot. Voucher specimens were collected for each species and were subsequently identified by P.K. Hoo based on the reference materials at the Herbarium of Forest Research Institute Malaysia (FRIM).

\section{Data analysis}

Principal component analysis (PCA) was conducted to assess the degree of habitat heterogeneity among the 17 plots based on the two habitat variables (leaf litter thickness, and canopy cover), four topographic variables (elevation, slope, aspect, and ruggedness index) and two vegetation variables (number of vascular plant individuals and number of vascular plant species). The abundance of vascular plant species was not included in the PCA analysis due to the number of missing values in the dataset and the absence of certain plant species in plots. We visually explored the PCA plot for habitat heterogeneity according to the plots' locations on the limestone hill (northern part, southern part, and central part). The analysis was done using R (Supplemental File 2).

Correction tests were performed to examine any significant relationships between the abundance of snails and each of the habitat, vegetation, and topographic variables. We excluded 43 vascular plant species that were recorded only in one plot before statistical analysis to obtain vegetation data. The final dataset consisted of the abundance data for 20 vascular plant species from 17 plots.

As the data were not normally distributed, we used Spearman correlation testing based on both null-hypothesis significance testing and corroborated our analysis by using the Bayes factor (BF10) (Kass \& Raftery, 1995). Our conclusion is based on the inference of both frequentist ( $p$ values) and Bayesian (Bayes factor) analyses. All analyses were performed using JASP software version 0.12.2 (JASP Team, 2020; Supplemental File 3).

There was either complete or partial missing microclimatic data from July for some of the plots, so we did not calculate the mean values for each of the microclimatic variables per month. Hence, we could not perform rigorous statistical analysis to test the relationship between the microclimatic variables and the abundance of snails in the plot. Nevertheless, we explored the relationships between the abundance of snails and microclimatic variables by plotting the mean of each sampled plot's daily microclimatic variables patterns. We calculated the daily mean air humidity, minimum air humidity, mean air temperature, maximum air temperature, mean soil temperature, and maximum soil temperature.

PeerJ reviewing PDF | (2020:09:53097:3:0:NEW 5 Jul 2021) 
179

180

181

182

183

184

185

186

187

188

189

190

191

192

193

194

195

196

197

198

199

200

201

202

203

204

205

206

207

208

209

210

211

212

213

214

215

216

217

The numbers of living specimens collected over the four CMR sessions are shown in Supplemental File 1. Living specimens were found in six out of seven plots on the northern part of the hill; none were found in plots on the central and southern parts (Supplemental File 1). The smallest marked specimen was $9 \mathrm{~mm}$ (shell width), and the majority of the marked snails were subadult and adult (Supplemental File 1). The recapture rates were greater than $80 \%$ for the three plots with more than ten snails recorded during the pilot survey and the first capture session of CMR (A-Polli2, APolli7, and A-Polli9, see Table 1 - 4 in Supplemental File 1), except for two recapture sessions in plot A-Polli2 (23\% and 67\%). The recapture rates were between 50\% and $100 \%$ for the two plots with less than ten snails.

Of the five plots examined in the CMR study, plot A-Polli2 had the highest population size of Pollicaria elephas (Table 1), and the calculated population density was estimated to be approximately 57 individuals for that plot and its surrounding area. The highest number of snails recorded per sampling event per plot was 26 specimens in plot A-Polli2 (Table 2 in Supplemental File 1). The snails' population density in the sampling plots varied only slightly during the different sampling sessions for each plot (Supplemental File 1).

\section{Effect of environmental variables on snail occurrence and abundance}

The first three PCA axes explained $78.7 \%$ of the habitat, topography, and vegetation variations between plots (Fig. 3, Supplemental File 4, Supplemental File 5). As shown in Fig. 3, the PCA plot did not show apparent differences between the plots in the northern part (most of the plots with living $P$. elephas) and the southern part (all plots without living $P$. elephas) on the limestone hill. The abundance of $P$. elephas per plot was not correlated with canopy cover, leaf litter thickness, elevation, aspect, slope, and the ruggedness of the habitat (Table 2).

The plot A-Polli9 with the higher number of living snails (15 - 16 individuals) had a soil mean temperature lower than $25^{\circ} \mathrm{C}$, and maximum temperature lower than $26^{\circ} \mathrm{C}$ (Fig. 4). However, the two plots, namely D-P1 and D-P11, at the southern part of the hill with no snails recorded had a similar mean and maximum soil temperature $\left(\sim 25^{\circ} \mathrm{C}\right)$ to the plot A-Polli9.

All the plots at the southern and northern parts of the hill had a similar mean temperature with differences smaller than $1{ }^{\circ} \mathrm{C}$ during most of the days, with the exception of plots D-P1 and D-P3 (Fig. 5). There were no significant differences in the mean temperature among plot A-Polli9 with a high number of living snails (15-16 individuals), plot A-Polli3 with few living snails (one to two individuals), and other plots without living snails. The plots with a higher mean humidity (85\% $100 \%$ ) at the southern part of the hill did not harbour $P$. elephas as compared to plots with lower humidity $(75 \%-93 \%)$ at the northern part of the hill (Fig. 6).

\section{Association between the abundance of $P$. elephas and vegetation}

Sixty-three taxa of vascular plants were recorded in the 17 plots. Species identifications were obtained for 46 species. The identity of 14 species could only be confirmed at the genus level, and 
218 the remaining three species could not be identified. Altogether 43 vascular plant species were

219

220

221

222

223

224

225

226

227

228

229

230

231

232

233

234

235

236

237

238

239

240

241

242

243

244

245

246

247

248

249

250

251

252

253

254

255

256 recorded in only one plot, of which 27 species were singletons (Table 3). The number of species per plot ranged between three and 11 species, and the number of individuals ranged between four and 42 (Supplemental File 4).

The abundance of four vascular plant species were positively correlated with the abundance of the land snails based on the null-hypothesis significance testing $(\mathrm{p}<0.05)$ and Bayes factor $(\mathrm{BF} 10)$ (Table 4, Supplemental File 7). Of these four species, Diospyros toposia var. toposoides (Ebenaceae) was the only plant species found in plots with and without living snails. Two plant species, namely, Croton cascarilloides (Euphorbiaceae) and Kibatalia laurifolia (Apocynaceae), were recorded only in two plots (A-P0 and A-Polli9). Another plant species, Mallotus peltatus (Euphorbiaceae), was recorded in only three plots (A-P0, A-P2 and A-Polli2). The total number of vascular plants and plant species was not correlated with the abundance of snails in the plots (Table 2).

\section{Discussion}

Synecology studies have focused on the association of habitat features and the composition of communities of land snails (Müller et al., 2005). However, autecology studies on single species in their natural habitat are scarce. The two different approaches of ecology have developed independently, although the knowledge of both is necessary to understand the ecology of an individual population within a species or the whole ecosystem. A broader understanding of a species' biogeography starts with the knowledge of the species' autecology on a local scale (Hugall, et al., 2002). Unfortunately, studies on the responses to environmental variables by individual species of large land snails in the tropical ecosystem are lacking (Horsák et al., 2007).

\section{Spatial distribution and population density of $P$. elephas}

The capture-mark-recapture technique has been used for estimation of population size and density for land snails (Blinn, 1963; Hänsel et al., 1999; Standish et al., 2002; Parkyn et al., 2014). Previous studies on other land snails showed that the capture rate using the CMR technique can be very high, with up to an $85 \%$ recapture rate after one year (Kleewein, 1999). In our study, the recapture rates varied by plot. Using this technique, we found that $P$. elephas can achieve high population densities, between three and four individuals per square meter, in suitable habitats at the northern part of the examined limestone hill. We could not find other population density studies on similarly-sized caenogastropod land snails for comparison. However, studies on similarly-sized pulmonate land snails showed that snails can occur in very low densities: less than one individual per $\mathrm{m}^{2}$ to very high densities of up to 100 individuals per $\mathrm{m}^{2}$ for Limicolaria martensiana (Owen, 1969). However, Owen (1969) did not investigate environmental factors that could determine the variation of densities in different population.

We could not find $P$. elephas in the southern part of the limestone hill, while large populations occurred on the northern part of the limestone hill. All examined plots were on the same limestone outcrop, with generally similar climatic condition, soil conditions, and land snail communities (Foon et al., 2017). Furthermore, there were no apparent differences in environmental variables in 
257 the microclimate, topography, habitat, and vegetation between the northern and southern part of 258 the limestone hill.

259 However, it is unclear why the snails from high-density spots did not migrate to the other spots at

260

261

262

263

264

265

266

267

268

269

270

271

272

273

274

275

276

277

278

279

280

281

282

283

284

285

286

287

288

289

290

291

292

293

294

295

296

297 the same hill with similar habitat. The dispersal ability of this species was not determined in this study. Nevertheless, the dispersal distances for other similar-sized land snails are very short, ranging from meters to tens of meters per year (Baur, 1986; Schilthuizen et al., 2005; Edmorthy et al., 2012; Ozgo and Bogucki, 2011; Kramarenko, 2014). One possible explanation could be the homing behaviour found in certain snail species (Rollo \& Wellington, 1981, Tomiyama, 1992; Stringer et al., 2018) with highly specialised habitat requirements. These species are not migrating far from their favoured spot and can have narrow-ranged endemics occurring unevenly across a large landscape. Another possible explanation may be that an unfavourable habitat prevents dispersal of this species to isolated spots with suitable habitat.

Although the environmental variables included in this study were unlikely to determine the absence and presence of this species in different parts of the hill, the heterogeneity of population densities in the plots at the northern part of the hill showed that higher abundance of $P$. elephas could be associated with lower soil temperatures. This is expected as P. elephas is a grounddwelling land snail. From our observation on the snails' behaviour in the field and in captive populations, snails were active during the night where they were seen feeding on leaf litter. In the day, the snails could be found burying themselves underneath leaf litter. Living snails in the field were never found attached to vegetation or rocks above ground. Hence, we can assume that a constant and relatively low soil ground temperature and a lower air temperature and higher humidity at night is important for the population to thrive (Supplemental File 8).

\section{Association between snail abundance and abundance of plant species}

Previous studies on the association between plants and specific land snail species have been conducted outside of the tropical regions (Blinn, 1963; Pollard, 1975; Cowie, 1985; Hänsel et al., 1999; Standish et al., 2002; Burrell et al., 2007; Horsák et al., 2011; Parkyn et al., 2013, 2014). Most of these studies suggested that plants act as shelters for land snails (Blinn, 1963; Pollard, 1975; Cowie, 1985; Standish et al., 2002; Burrell et al., 2007; Parkyn et al., 2014).

The abundance of $P$. elephas is positively associated with a relatively common vascular plant, Diospyros toposia var. toposoides, on the limestone hill. The other three comparatively uncommon species, namely, Croton cascarilloides, Kibatalia laurifolia, and Mallotus peltatus were also positively correlated with the snails' abundance. All of the three species are only found in plots with living snails (Table 3). However, it is important to note that due to the nature of high heterogeneity of vascular plants in the forest, as well as the 43 vascular plant species that were recorded in only one plot, there were only two plots for Kibatalia laurifolia and Croton cascarilloides, respectively, and three plots for Mallotus peltatus. Also, this indicates that the presence of the three plant species is not necessary for the presence of the snails as these plants were not found in other plots where snails were present. Hence, future studies of carefully-selected sites with different abundances of living snails and our identified species should be conducted to verify the possible causal relationship. 
298

299

300

301

302

303

304

305

306

307

308

309

310

311

312

313

314

315

316

317

318

319

320

321

322

323

324

325

326

327

328

329

330

331

332

333

334

335

336

337

338

339

A plausible explanation for this relationship could be that the leaf litter from these plant species is suitable for the snails' diet. However, it is also possible that rather than a direct causal relationship, both plants and snails prefer the same parameters of the local environment. A specially designed experiment is needed to test these hypotheses. To our knowledge, there were no in situ experiments on food preferences of land snails conducted in the field. However, there have been laboratory experiments conducted with decaying leaves of selected plant species (Puslednik, 2002; Proćków et al., 2013). In situ experiments on food preferences in a tropical rainforest are challenging because identifying leaf litter from plants is difficult, as plants are very species rich even within a small area, as was shown in this study (Crowther, 1982, 1987a, 1987b). We cannot rule out the hypothesis that plants and leaf litters provide shelter for land snails (e.g. Blinn, 1963; Pollard, 1975; Cowie, 1985; Standish et al., 2002; Burrell et al., 2007; Parkyn et al., 2014).

There were single-species land snail studies to investigate the effects of vegetation on the population density in non-tropical (Hänsel et al., 1999; Horsák et al., 2011; Barrientos, 2000, 2019; Caldwell et al., 2014) and tropical regions (Barrientos, 2000). However, these studies relate the abundance of land snails, either with the general characteristic of vegetation structures (e.g., herbaceous vegetation in Hänsel et al., 1999; sparse herb vegetation in Horsák et al., 2011; thickness of herbaceous vegetation in Barrientos, 2000) or common plant species in the study sites (e.g., Barrientos, 2000; Caldwell et al., 2014). These studies could not establish proof of causation between specific plant species and the abundance of land snails. Although we could not confirm the in-depth association between the vascular plant species and snail feeding ecology, we were able to identify candidate plants to be included in future experiments. It would be worthwhile to investigate the $\mathrm{pH}$ and nutrient content of the plant species as the possible food sources and shelters for the land snail since there was an association between snail abundance and particular plant species.

\section{Other factors that may affect the distribution and density of land snails}

The distribution and density of $P$. elephas may be influenced by factors that were not investigated in this study, such as calcium availability, $\mathrm{pH}$ of the substrates, and predators. In the non-limestone forests, calcium availability plays a major role in determining the population density of snails (Gardenfors, 1992; Graveland \& Van der Wal, 1996; Skeldon et al., 2007). However, we assumed that calcium availability may not vary significantly because all the plots were located next to the limestone outcrops (Crowther, 1987a); therefore, calcium availability may not be a factor that requires further attention among the plots.

Typically, the $\mathrm{pH}$ of the substrates (soil and leaf litter) will be affected by the bedrock, and the variation of $\mathrm{pH}$ among the plots on the limestone hills were very small (e.g. Crowther, 1982). However, leaf $\mathrm{pH}$ and leaf litter can vary significantly among different plant species (Cornelissen et al., 2011; Tao et al., 2019). However, a study of other land snails in another part of the world suggested that snail density correlated with calcium content and, to a lesser extent, with the $\mathrm{pH}$ of the litter layer (Graveland \& Van der Wal, 1996).

Lastly, predation pressure could also explain snails' density distribution patterns (Abramsky et al., 1992; Meyer \& Cowie, 2010; Gerlach et al., 2020). Unfortunately, data on population densities and life histories for predators were not available from this study.

PeerJ reviewing PDF | (2020:09:53097:3:0:NEW 5 Jul 2021) 
340

341

342

343

344

345

346

347

348

349

350

351

352

353

354

355

356

357

358

359

360

361

362

363

364

365

366

367

368

369

370

371

372

\section{Conclusion}

We determined the ecological aspects of $P$. elephas in terms of the habitat, topography, microclimate, and vegetation variables. We also found that ground temperature and a few vascular plant species were positively associated with snail abundance. Although our study was limited by its short duration and the absence of replicate sites on other hills, our findings can be used to formulate testable hypotheses when another population of this snail is found on further sites. After this exploratory study, we suggest a more focused, hypothesis-driven study to determine: (1) how the microclimates variations affect the land snails' activities during the day and night; (2) the roles of the four vascular plant species that were found associated with living snails as food or shelter.

\section{Acknowledgements}

We thank Jaap Vermeulen and the two anonymous reviewers for their constructive comments. We want to thank Richard Chung Cheng Kong, the curator of The Herbarium in Forest Research Institute Malaysia (KEP), for allowing us to access the herbarium and its facilities. Postar Miun, a field botanist from Forest Research Center (FRC), has helped tremendously identify plant voucher specimens, for which we are grateful.

\section{References}

Abramsky, Z., Shachak, M., Subach, A., Brand, S., \& Alfia, H. (1992). Predator-prey relationships: rodent-snail interactions in the Central Negev Desert of Israel. Oikos, 128-133.

Alcoy, J. C. O. (2013). The Schnabel Method: An ecological approach to productive vocabulary size estimation. International Proceedings of Economics Development and Research, 68, 19.

Barrientos, Z. (2000). Population dynamics and spatial distribution of the terrestrial snail Ovachlamys fulgens (Stylommatophora: Helicarionidae) in a tropical environment. Revista de Biología Tropical, 48(1), 71-87.

Barrientos, Z. (2019). Demography of the land snail Tikoconus (Tikoconus) costarricanus (Stylommatophora: Euconulidae) in tropical low montane and premontane forests, Costa Rica. Revista de Biología Tropical, 67(6). 1449-1460.

Baur, B. (1986). Patterns of dispersion, density and dispersal in alpine populations of the land snail Arianta arbustorum (L.) (Helicidae). Ecography, 9(2), 117-125.

Berry, A. J. (1962). The growth of Opisthostoma (Plectostoma) retrovertens Tomlin, a minute cyclophorid from a Malayan limestone hill. Journal of Molluscan Studies, 35(1), 46-49.

Berry, A. J. (1963). Growth and variation of the shell in certain Malayan limestone hill snails. Journal of Molluscan Studies, 35(5), 203-206. 
373 Berry, A. J. (1965). reproduction and breeding fluctuations in Hydrocena monterosatiana a 374 Malayan limestone archaeogastropod. In Proceedings of the Zoological Society of London, 144(2), 375 219-228.

376 Berry, A. J. (1966). Population structure and fluctuations in the snail fauna of a Malayan limestone 377 hill. Journal of zoology, 150(1), 11-27.

378 Blinn, W. C. (1963). Ecology of the land snails Mesodon thyroidus and Allogona profunda. 379 Ecology, 44(3), 498-505.

380 Boag, D. A. (1985). Microdistribution of three genera of small terrestrial snails (Stylommatophora: 381 Pulmonata). Canadian Journal of Zoology, 63(5), 1089-1095.

382 Burrell, C., Scott, B., \& Yen, A. L. (2007). Habitat Preferences of the Otway Black snail 383 Victaphanta Compacta (Cox and Hedley, 1912) (Rhytididae). The Victorian Naturalist, 124(4), 384 204-209.

385 Caldwell, R. S., Copeland, J. E., Mears, G. L., \& Douglas, D. A. (2014). Notes on the natural 386 history and ecology of Inflectarius magazinensis (Pilsbry and Ferriss, 1907) (Gastropoda: 387 Polygyridae), the Magazine Mountain Shagreen. American Malacological Bulletin, 32(2), 211388216.

389 Chan, S. Y. (1997) On Pollicaria elephas (de Morgan,1885) from Perak, West Malaysia. The 390 Papustyla, 11 (3) 11-12.

391 Chan, S. Y. (1998) A brief collecting trip to Perak, West Malaysia. part two. The Papustyla, 12 (2) $392 \quad 1-2$.

393 Clements, R., Ng, P. K., Lu, X. X., Ambu, S., Schilthuizen, M., \& Bradshaw, C. J. (2008). Using 394 biogeographical patterns of endemic land snails to improve conservation planning for limestone 395 karsts. Biological conservation, 141(11), 2751-2764.

396 Conrad, O., Bechtel, B., Bock, M., Dietrich, H., Fischer, E., Gerlitz, L., Wehberg, J., Wichmann, 397 V., and Böhner, J. (2015): System for Automated Geoscientific Analyses (SAGA)v. 2.1.4, Geosci. 398 Model Dev., 8, 1991-2007.

399 Cornelissen, J. H., Sibma, F., Van Logtestijn, R. S., Broekman, R. A., \& Thompson, K. (2011). 400 Leaf $\mathrm{pH}$ as a plant trait: Species-driven rather than soil-driven variation. Functional Ecology, 401 25(3), 449-455.

402 Cowie, R. H. (1985). Microhabitat choice and high temperature tolerance in the land snail Theba 403 pisana (Mollusca: Gastropoda). Journal of Zoology, 207(2), 201-211.

404 Crowther, J. (1982). Ecological observations in a tropical karst terrain, West Malaysia. I. 405 Variations in topography, soils and vegetation. Journal of Biogeography, 65-78.

406 Crowther, J. (1987a). Ecological observations in tropical karst terrain, West Malaysia. II. Rainfall 407 interception, litterfall and nutrient cycling. Journal of Biogeography, 145-155. 
408 Crowther, J. (1987b). Ecological observations in tropical karst terrain, West Malaysia. III. 409 Dynamics of the vegetation-soil-bedrock system. Journal of biogeography, 157-164.

410 Dvořáková, J., \& Horsák, M. (2012). Variation of snail assemblages in hay meadows disentangling 411 the predictive power of abiotic environment and vegetation. Malacologia, 55(1), 151-162.

412 Edworthy, A. B., Steensma, K. M. M., Zandberg, H. M., \& Lilley, P. L. (2012). Dispersal, home413 range size, and habitat use of an endangered land snail, the Oregon forestsnail (Allogona 414 townsendiana). Canadian journal of zoology, 90(7), 875-884.

415 Foon, J. K., Clements, G. R., \& Liew, T. S. (2017). Diversity and biogeography of land snails 416 (Mollusca, Gastropoda) in the limestone hills of Perak, Peninsular Malaysia. ZooKeys, (682), 141794.

418 Gardenfors, U. (1992). Effects of artificial liming on land snail populations. Journal of applied 419 Ecology, 50-54.

420 GBIF.org (12 October 2018) GBIF Occurrence Download https://doi.org/10.15468/dl.wajiyx

421 Gerlach, J., Barker, G. M., Bick, C. S., Bouchet, P., Brodie, G., Christensen, C. C., Collins, T., 422 Coote T., Cowie, R. H., Fiedler G. C., Griffiths, O. L., Florens F. B. V., Hayes K. Kim, A. J., 423 Meyer, J.-Y, . Meyer, W. M. III, Richling, I., Slapcinsky, J. D., Winsor L., \& Yeung, N. W. (2020). 424 Negative impacts of invasive predators used as biological control agents against the pest snail 425 Lissachatina fulica: the snail Euglandina 'rosea' and the flatworm Platydemus manokwari. 426 Biological Invasions, 1-35.

427 Graveland, J., \& Van der Wal, R. (1996). Decline in snail abundance due to soil acidification 428 causes eggshell defects in forest passerines. Oecologia, 105(3), 351-360.

429 Hänsel, N., Walther, C., \& Plachter, H. (1999). Influence of land use and habitat parameters on 430 populations of Candidula unifasciata and Helicella itala (Gastropoda, Helicidae) on calcareous 431 grassland. Verhandlungen-Gesellschaft fur Okologie, 29, 363-372.

432 Horsák, M., Hájek, M., Tichý, L., \& Juřičková, L. (2007). Plant indicator values as a tool for land 433 mollusc autecology assessment. Acta Oecologica, 32(2), 161-171.

434 Horsák, M., Škodová, J., \& Cernohorsky, N. H. (2011). Ecological and historical determinants of 435 Western Carpathian populations of Pupilla alpicola (Charpentier, 1837) in relation to its present 436 range and conservation. Journal of Molluscan Studies, 77(3), 248-254.

437 Hugall, A., Moritz, C., Moussalli, A., \& Stanisic, J. (2002). Reconciling paleodistribution models 438 and comparative phylogeography in the Wet Tropics rainforest land snail Gnarosophia 439 bellendenkerensis (Brazier 1875). Proceedings of the National Academy of Sciences, 99(9), 6112440 6117.JASP Team (2020). JASP (Version 0.12.2) (https://jasp-stats.org/)

441 Kass, R. E., \& Raftery, A. E. (1995). Bayes factors. Journal of the American Statistical association, 442 90(430), 773-795. 
443 Kleewein, D. (1999). Population size, density, spatial distribution and dispersal in an Austrian 444 population of the land snail Arianta arbustorum styriaca (Gastropoda: Helicidae). Journal of 445 Molluscan Studies, 65(3), 303-315.

446 Kongim, B., Sutcharit, C., Tongkerd, P., Tan, S. H. A., Quynh, N. X., Naggs, F., \& Panha, S. 447 (2010). Karyotype variation in the genus Pollicaria (Caenogastropoda: Pupinidae). Zoological 448 Studies, 49(1), 125-131.

449 Kongim, B., Sutcharit, C., Naggs, F. \& Panha, S. (2013). Taxonomic revision of the elephant 450 pupinid snail genus Pollicaria Gould, 1856 (Prosobranchia, Pupinidae)". ZooKeys 287: 19-40. 451 doi:10.3897/zookeys.287.4617.

452 Kramarenko, S. (2014). Active and passive dispersal of terrestrial mollusks a review. Ruthenica, $45324(1)$.

454 Liew, T. S., Kok, A. C., Schilthuizen, M., \& Urdy, S. (2014b). On growth and form of irregular 455 coiled-shell of a terrestrial snail: Plectostoma concinnum (Fulton, 1901) (Mollusca: 456 Caenogastropoda: Diplommatinidae). PeerJ, 2, e383.

457 Martin, K., \& Sommer, M. (2004). Relationships between land snail assemblage patterns and soil 458 properties in temperate-humid forest ecosystems. Journal of Biogeography, 31(4), 531-545.

459 Meyer, W. M., \& Cowie, R. H. (2010). Feeding preferences of two predatory snails introduced to 460 Hawaii and their conservation implications. Malacologia, 53(1), 135-144.

461 Minton, R. L., Harris, P. M., \& North, E. (2017). Diversity and taxonomy of Vietnamese Pollicaria 462 (Gastropoda, Pupinidae). Zoosystematics and Evolution, 93, 95.

463 de Morgan, J. (1885) Note sur quelques espèces nouvelles de Mollusques terrestres réceuillis dans 464 le Peninsula Malaise. Le Naturaliste 7: 68-70.

465 von Moellendorff, O. (1886) The landshells of Perak. Journal of the Asiatic Society of Bengal 55: 466 299-316.

467 Müller, J., Strätz, C., \& Hothorn, T. (2005). Habitat factors for land snails in European beech 468 forests with a special focus on coarse woody debris. European Journal of Forest Research, 124(3), $469233-242$.

470 Owen, D. F. (1969). Ecological aspects of polymorphism in an African land snail, Limicolaria 471 martensiana. Journal of Zoology, 159(1), 79-96.

472 Ozgo, M., Bogucki, Z. (2011). Colonisation, stability, and adaptation in a transplant experiment 473 of the polymorphic land snail Cepaea nemoralis (Gastropoda: Pulmonata) at the edge of its 474 geographical range. Biological Journal of the Linnean Society, 104(2), 462-470.

475 Pain, T. (1974) The land operculate genus Pollicaria Gould (Gastropoda), a systematic revision. 476 Journal of Conchology 28: 173-178.

477 Parkyn, J., \& Newell, D. A. (2013). Australian land snails a review of ecological research and 478 conservation approaches. Molluscan research, 33(2), 116-129. 
479 Parkyn, J., Brooks, L., \& Newell, D. (2014). Habitat use and movement patterns of the endangered 480 land snail Thersites mitchellae (Cox, 1864)(Camaenidae). Malacologia, 57(2), 295-307.

481 Pollard, E. (1975). Aspects of the ecology of Helix pomatia L. The Journal of Animal Ecology, $482 \quad 305-329$.

483 Proćków, M., Drvotová, M., Juřičková, L., \& Kuźnik-Kowalska, E. (2013). Field and laboratory 484 studies on the life-cycle, growth and feeding preference in the hairy snail Trochulus hispidus (L., 485 1758)(Gastropoda: Pulmonata: Hygromiidae). Biologia, 68(1), 131-141.

486 Puslednik, L. (2002). Dietary preferences of two species of Meridolum in southeastern Australia. 487 Molluscan Research, 22(1), 17-22.

488 QGIS Development Team (2018). QGIS Geographic Information System. Open Source Geospatial 489 Foundation Project. http://qgis.osgeo.org

490 Riley, S. J., DeGloria, S. D., \& Elliot, R. (1999). Index that quantifies topographic heterogeneity. 491 intermountain Journal of sciences, 5(1-4), 23-27.

492 Rollo, C. D., \& Wellington, W. G. (1981). Environmental orientation by terrestrial Mollusca with 493 particular reference to homing behaviour. Canadian Journal of Zoology, 59(2), 225-239.

494 Schilthuizen M, Rosli R, Ali AMM, Salverda M, van Oosten H, Bernard H, Ancrenaz M, 495 Lackman- Ancrenaz I. 2003. The ecology and demography of Opisthostoma (Plectostoma) 496 concinnum s.l. (Gastropoda: Diplommatinidae) on limestone outcrops along the Kinabatangan 497 river. In: Mohamed M, Goossens B, Ancrenaz M, Andau M, eds. Lower Kinabatangan scientific 498 expedition. Kota Kinabalu, Universiti Malaysia Sabah, 55-71.Schilthuizen, M., Scott, B. J., 499 Cabanban, A. S., \& Craze, P. G. (2005). Population structure and coil dimorphism in a tropical 500 land snail. Heredity, 95(3), 216-220.

501 Skeldon, M. A., Vadeboncoeur, M. A., Hamburg, S. P., \& Blum, J. D. (2007). Terrestrial gastropod 502 responses to an ecosystem-level calcium manipulation in a northern hardwood forest. Canadian 503 Journal of Zoology, 85(9), 994-1007.

504 Standish, R. J., Bennett, S. J., \& Stringer, I. A. (2002). Habitat use of Tradescantia fluminensis by 505 Powelliphanta traversi. Science for Conservation, 195A, 35.

506 Stringer, I. A. N., Parrish, G. R., \& Sherley, G. H. (2018). Homing, dispersal and mortality after 507 translocation of long-lived land snails Placostylus ambagiosus and P. hongii (Gastropoda:

508 Bothriembryontidae) in New Zealand. Molluscan Research, 38(1), 56-76.

509 Tao, J., Zuo, J., He, Z., Wang, Y., Liu, J., Liu, W., \& Cornelissen, J. H. (2019). Traits including 510 leaf dry matter content and leaf $\mathrm{pH}$ dominate over forest soil $\mathrm{pH}$ as drivers of litter decomposition 511 among 60 species. Functional Ecology, 33(9), 1798-1810.

512 Tomiyama, K. (1992). Homing behaviour of the giant African snail, Achatina fulica 513 (Ferussac)(Gastropoda; Pulmonata). Journal of Ethology, 10(2), 139-146. 


\section{Table $\mathbf{1}$ (on next page)}

Population estimation for Pollicaria elephas for each plot based on capture-markrecapture technique and Schnabel index. 
1

\begin{tabular}{|c|c|c|}
\hline Plots & Population density & $\begin{array}{c}\text { Population estimation by } \\
\text { CMR (number of snails) }\end{array}$ \\
\hline A-Polli2 & $23.0 \pm 3.4$ & 56.9 \\
\hline A-Polli9 & $15.8 \pm 1.6$ & 20.8 \\
\hline A-Polli7 & $17.4 \pm 2.8$ & 19.5 \\
\hline A-Polli3 & $1.4 \pm 0.5$ & 2.0 \\
\hline A-P2 & $6.3 \pm 2.1$ & 12.1 \\
\hline
\end{tabular}

2 a Average number of snails \pm standard deviation for all of the CMR sessions at each $8 \mathrm{~m}^{2}$ plot. 


\section{Table 2 (on next page)}

Correlation between the abundance of Pollicaria elephas for each plot with the habitat and topographic parameters. 
1

\begin{tabular}{|l|l|l|l|l|}
\hline Habitat and topographic variables & $\begin{array}{l}\text { Bayesian } \\
\text { Kendall's Tau } \\
\text { Correlations }\end{array}$ & BF $_{10}$ & $\begin{array}{l}\text { Kendall's } \\
\text { Tau } \\
\text { Correlations }\end{array}$ & p-value \\
\hline $\begin{array}{l}\text { Number of vascular plant individuals } \\
\text { for each plot }\end{array}$ & -0.186 & 0.512 & -0.186 & 0.353 \\
\hline $\begin{array}{l}\text { Number of vascular plant species for } \\
\text { each plot }\end{array}$ & 0.128 & 0.392 & 0.128 & 0.525 \\
\hline \begin{tabular}{l} 
Canopy cover (\%) \\
\hline Leaf litter thickness (cm)
\end{tabular} & 0.261 & 0.84 & 0.261 & 0.216 \\
\hline Elevation (meters) & 0.154 & 0.437 & 0.154 & 0.436 \\
\hline $\begin{array}{l}\text { Aspect (counter-clockwise in degrees } \\
\text { from 0 (due north) to 360 (again due } \\
\text { north)) }\end{array}$ & 0.086 & 0.504 & 0.183 & 0.355 \\
\hline Ruggedness index & & 0.343 & 0.086 & 0.662 \\
\hline Slope (degrees) & 0.092 & 0.372 & 0.092 & 0.669 \\
\hline
\end{tabular}




\section{Table 3 (on next page)}

Checklist and the number of individuals per vascular plant species in each plot. 


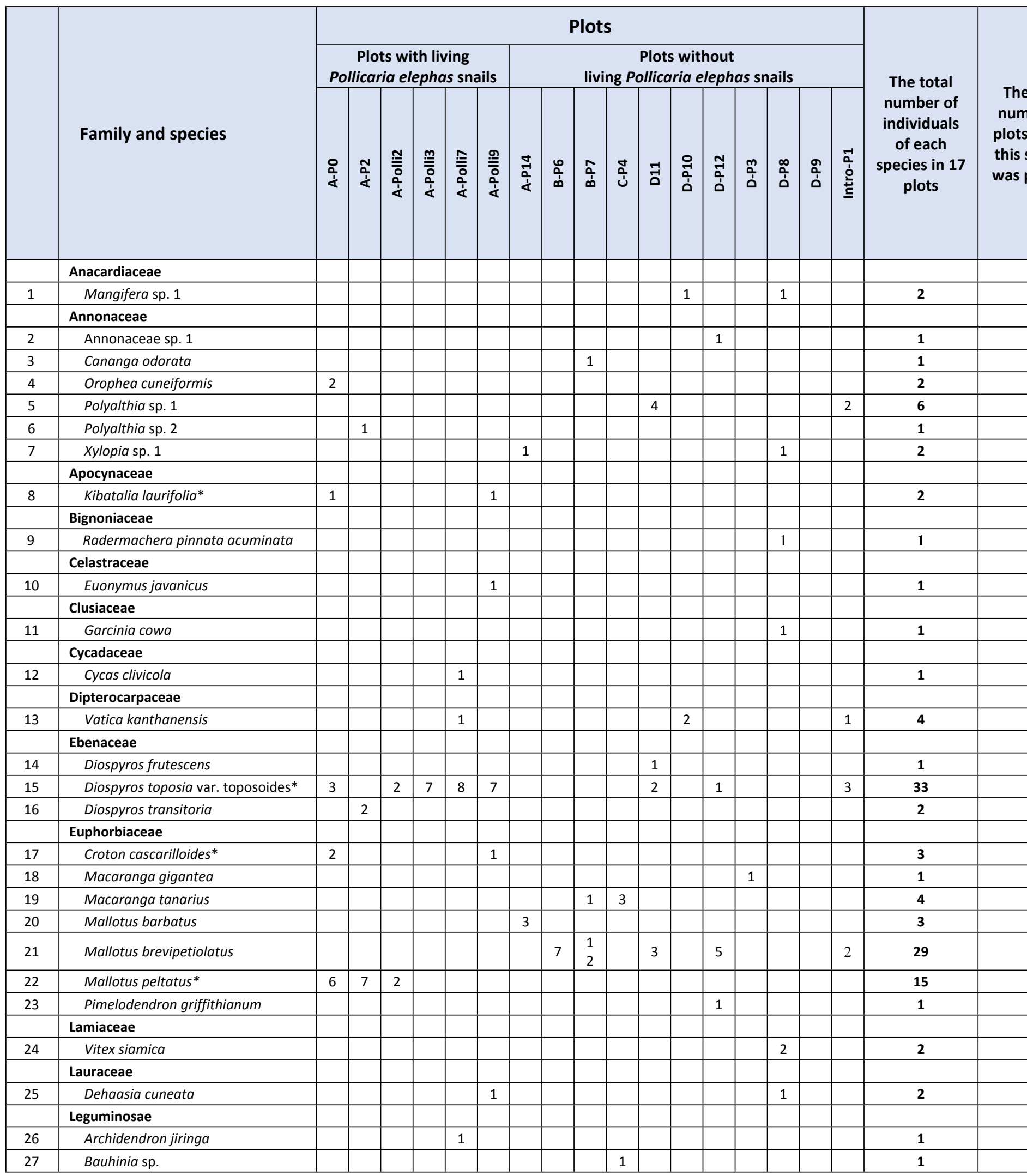




\begin{tabular}{|c|c|c|c|c|c|c|c|c|c|c|c|c|c|c|c|c|c|c|c|}
\hline & Malvaceae & & & & & & & & & & & & & & & & & & \\
\hline 28 & Hibiscus macrophyllus & & & & & & & 8 & & & & & & & & & & & 8 \\
\hline 29 & Leptonychia caudata & & & & & & & & & 6 & & 5 & & & & & & 5 & 16 \\
\hline 30 & Pterospermum acerifolium & & & & & 1 & & & & & & & & & & & & & 1 \\
\hline \multirow[t]{2}{*}{31} & Sterculia rubiginosa & & & & & & & & & & & & & 1 & & & & & 1 \\
\hline & Melastomataceae & & & & & & & & & & & & & & & & & & \\
\hline \multirow[t]{2}{*}{32} & Memecylon lilacinum & & & & & & & & & & & & 8 & & & & & & 8 \\
\hline & Meliaceae & & & & & & & & & & & & & & & & & & \\
\hline \multirow[t]{2}{*}{33} & Aglaia grandis & & & & & 1 & & & & & & & & & & & & & 1 \\
\hline & Moraceae & & & & & & & & & & & & & & & & & & \\
\hline 34 & Ficus fistulosa & & & & & & & 1 & & & & & & & & & & & 1 \\
\hline 35 & Ficus hispida & & & & & & & & & & 2 & & & & & & & & 2 \\
\hline 36 & Ficus schwarzii & & & & & & & & & 1 & & & & & & & & & 1 \\
\hline 37 & Ficus sp. 1 & & & & & & & & & & 1 & & & & & & & & 1 \\
\hline \multirow[t]{2}{*}{38} & Ficus sp. 2 & & & & & & & & & & & & & & 2 & & & & 2 \\
\hline & Palmae & & & & & & & & & & & & & & & & & & \\
\hline 39 & Arenga westerhoutii & & 4 & & & & & & & & & & & & 1 & & & & 5 \\
\hline 40 & Borassodendron machadonis & & 1 & & & & & & & & & & & & & & & & 1 \\
\hline \multirow[t]{2}{*}{41} & Caryota mitis & & & & & & & 1 & & & & & & & & & & & 1 \\
\hline & Pandanaceae & & & & & & & & & & & & & & & & & & \\
\hline \multirow[t]{2}{*}{42} & Pandanus piniformis & & & & & & & & & & & & 5 & & & 3 & 2 & & 10 \\
\hline & Phyllanthaceae & & & & & & & & & & & & & & & & & & \\
\hline 43 & Bridelia tomentosa & & & & & & & 1 & & & & & $\begin{array}{l}1 \\
0\end{array}$ & & & $\begin{array}{l}2 \\
5\end{array}$ & 8 & & 44 \\
\hline 44 & Cleistanthus gracilis & & & 1 & $\begin{array}{l}1 \\
5\end{array}$ & & & & 5 & & & & 3 & & & & & & 24 \\
\hline \multirow[t]{2}{*}{45} & Cleistanthus myrianthus & & 1 & & & & & & & & & & & & & & & 6 & 7 \\
\hline & Primulaceae & & & & & & & & & & & & & & & & & & \\
\hline 46 & Ardisia sp. & & & & & & & & & & & 2 & & & & & & & 2 \\
\hline \multirow[t]{2}{*}{47} & Myrsine perakensis & & & & & & & & & & & & & & & 1 & & & 1 \\
\hline & Rubiaceae & & & & & & & & & & & & & & & & & & \\
\hline 48 & Aidia densifolia & & & 3 & 2 & & & & & & & & 7 & & & 3 & 6 & & 21 \\
\hline 49 & Canthium sp. 1 & & & & & & & & & & & & & & & 3 & & & 3 \\
\hline 50 & Canthium sp. 2 & & & & & & & & & & & & & & & & & 4 & 4 \\
\hline \multirow[t]{2}{*}{51} & Saprosma sp. & & & & & & 1 & & & & & & & & & & & & 1 \\
\hline & Rutaceae & & & & & & & & & & & & & & & & & & \\
\hline 52 & Micromelum minutum & & & & & & & & & & & & & & & & & 1 & 1 \\
\hline 53 & Murraya paniculata & & & & 1 & 1 & 1 & & & 1 & & & & & & & & & 4 \\
\hline 54 & Rutaceae sp. 1 & & & & & & & & & & & & & & & & 2 & & 2 \\
\hline \multirow[t]{2}{*}{55} & Rutaceae sp. 2 & & & & & & & & & & & & & & & & & 1 & 1 \\
\hline & Salicaceae & & & & & & & & & & & & & & & & & & \\
\hline 56 & Homalium dasyanthum & & & & & & 2 & & & & & & & & & & & & 2 \\
\hline \multirow[t]{2}{*}{57} & Homalium grandifllorum & & & & & & & & & & & & 1 & & & & & & 1 \\
\hline & Sapindaceae & & & & & & & & & & & & & & & & & & \\
\hline \multirow[t]{2}{*}{58} & Paranephelium spirei & 1 & & & & & & & & & & & & & & & & & 1 \\
\hline & Sapotaceae & & & & & & & & & & & & & & & & & & \\
\hline \multirow[t]{2}{*}{59} & Isonandra perakensis & & & & & & & & & & & & 2 & & & & & & 2 \\
\hline & Violaceae & & & & & & & & & & & & & & & & & & \\
\hline \multirow[t]{2}{*}{60} & Rinorea bengalensis & 2 & 2 & 3 & 4 & 3 & 2 & & 5 & & & 2 & & 7 & & & & 6 & 36 \\
\hline & Indet & & & & & & & & & & & & & & & & & & \\
\hline 61 & Indet sp. 1 & & & & & & 2 & & & & & & & & & & & & 2 \\
\hline 62 & Indet sp. 2 & & & & & & & & & & & & & 1 & & & & & 1 \\
\hline 63 & Indet sp. 3 & & & & & & & & & & & & & 2 & & & & & 2 \\
\hline
\end{tabular}


2 * Plant species were a positive correlation between the abundances of plants and snails was 3 found. 


\section{Table 4 (on next page)}

Correlation between the abundance of Pollicaria elephas for each plot with the abundance of the vascular plant species. 


\begin{tabular}{|c|c|c|c|c|c|c|}
\hline Family & Species & $\begin{array}{c}\text { Occurrence } \\
\text { in the } 17 \\
\text { plots }\end{array}$ & $\begin{array}{c}\text { Bayesian } \\
\text { Kendall's Tau } \\
\text { Correlations }\end{array}$ & $\mathrm{BF}_{10}$ & $\begin{array}{l}\text { Kendall's Tau } \\
\text { Correlations }\end{array}$ & $p$-value \\
\hline Anacardiaceae & Mangifera sp. 1 & 2 & -0.243 & 0.735 & -0.243 & 0.295 \\
\hline Annonaceae & Polyalthia sp. 1 & 2 & -0.239 & 0.714 & -0.239 & 0.296 \\
\hline Annonaceae & Xylopia sp. 1 & 2 & -0.243 & 0.735 & -0.243 & 0.295 \\
\hline Apocynaceae & $\begin{array}{l}\text { Kibatalia } \\
\text { laurifolia }\end{array}$ & 2 & $0.527 *$ & 17.738 & $0.527 *$ & 0.023 \\
\hline Dipterocarpaceae & $\begin{array}{l}\text { Vatica } \\
\text { kanthanensis }\end{array}$ & 3 & -0.050 & 0.320 & -0.050 & 0.826 \\
\hline Ebenaceae & $\begin{array}{l}\text { Diospyros toposia } \\
\text { var. toposoides }\end{array}$ & 8 & $0.519 *$ & 15.604 & $0.519 *$ & 0.015 \\
\hline Euphorbiaceae & $\begin{array}{l}\text { Croton } \\
\text { cascarilloides }\end{array}$ & 2 & $0.499 *$ & 11.617 & $0.499 *$ & 0.030 \\
\hline Euphorbiaceae & $\begin{array}{l}\text { Macaranga } \\
\text { tanarius }\end{array}$ & 2 & -0.239 & 0.714 & -0.239 & 0.296 \\
\hline Euphorbiaceae & $\begin{array}{l}\text { Mallotus } \\
\text { brevipetiolatus }\end{array}$ & 5 & -0.398 & 3.139 & -0.398 & 0.070 \\
\hline Euphorbiaceae & Mallotus peltatus & 3 & $0.547^{*}$ & 23.867 & $0.547^{*}$ & 0.016 \\
\hline Lauraceae & $\begin{array}{l}\text { Dehaasia } \\
\text { cuneata }\end{array}$ & 2 & 0.162 & 0.454 & 0.162 & 0.485 \\
\hline Malvaceae & $\begin{array}{l}\text { Leptonychia } \\
\text { caudata }\end{array}$ & 3 & -0.302 & 1.167 & -0.302 & 0.187 \\
\hline Palmae & $\begin{array}{l}\text { Arenga } \\
\text { westerhoutii }\end{array}$ & 2 & 0.060 & 0.325 & 0.060 & 0.794 \\
\hline Pandanaceae & $\begin{array}{l}\text { Pandanus } \\
\text { piniformis }\end{array}$ & 3 & -0.298 & 1.133 & -0.298 & 0.187 \\
\hline Phyllanthaceae & $\begin{array}{l}\text { Bridelia } \\
\text { tomentosa }\end{array}$ & 4 & -0.350 & 1.854 & -0.350 & 0.116 \\
\hline Phyllanthaceae & $\begin{array}{l}\text { Cleistanthus } \\
\text { gracilis }\end{array}$ & 4 & 0.131 & 0.397 & 0.131 & 0.556 \\
\hline Phyllanthaceae & $\begin{array}{l}\text { Cleistanthus } \\
\text { myrianthus }\end{array}$ & 2 & 0.020 & 0.310 & 0.020 & 0.931 \\
\hline Rubiaceae & Aidia densifolia & 5 & 0.000 & 0.308 & 0.000 & 1.000 \\
\hline Rutaceae & $\begin{array}{l}\text { Murraya } \\
\text { paniculata }\end{array}$ & 4 & 0.370 & 2.279 & 0.370 & 0.112 \\
\hline Violaceae & $\begin{array}{l}\text { Rinorea } \\
\text { bengalensis }\end{array}$ & 10 & 0.257 & 0.809 & 0.257 & 0.223 \\
\hline
\end{tabular}

$1 * \mathrm{BF}_{10}>10,{ }^{* *} \mathrm{BF}_{10}>30, * * * \mathrm{BF}_{10}>100 ; * \mathrm{p}<0.05, * * \mathrm{p}<0.01, * * * \mathrm{p}<0.001$, ${ }^{\text {a }}$ The variance in

2 Macaranga tanarius is equal to 0 
Figure 1

Photographs of specimens of Pollicaria elephas and the study site.

(A) Male individual of Pollicaria elephas. Scale: $10 \mathrm{~mm}$. (B) and (C) Capture-mark-recapture experiment in the field. Different colours of nail polish were used to mark the shells of living Pollicaria elephas that were collected during different sampling sessions. (D) and (E) Habitat of Pollicaria elephas at two localities at northern part of the limestone hill. 

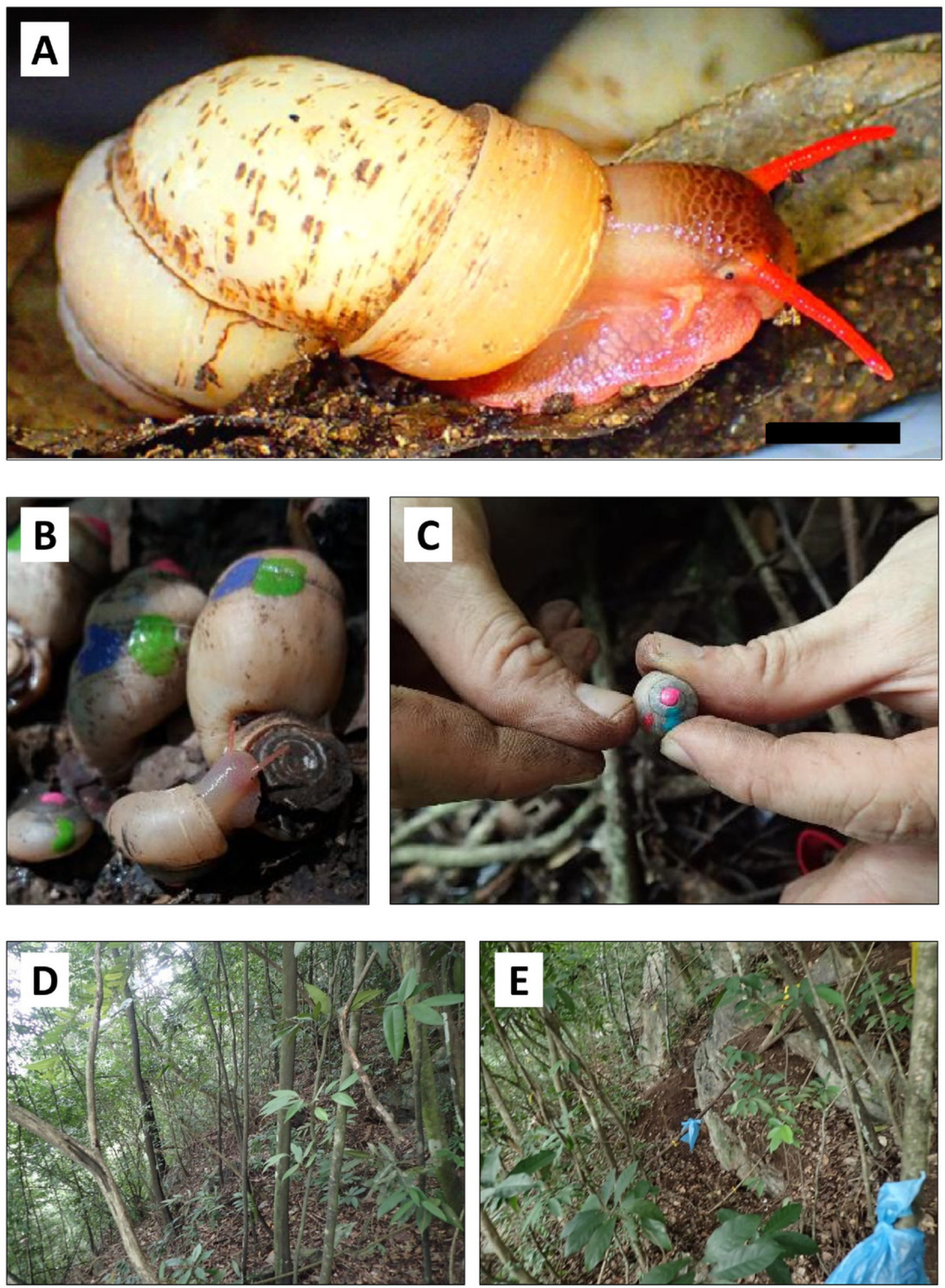


\section{Figure 2}

Study sites and location of the 17 studied plots at a limestone hill in the state of Perak, Malaysia.

(A) Topographic map showing the seven plots at the northern part, nine plots at the southern part and one plot (C-P4) at the central part of the hill. (B) Aerial photograph from the north-western flank (blue arrow) of the hill and location of the seven plots on a topographic map. Five of the plots were selected for the capture-mark-recapture study. The blue box indicates an area of $500 \mathrm{~m} \times 150 \mathrm{~m}$. (C) Aerial photograph from the southern flank (blue arrow) of the hill and the location of the nine plots on a topographic map.

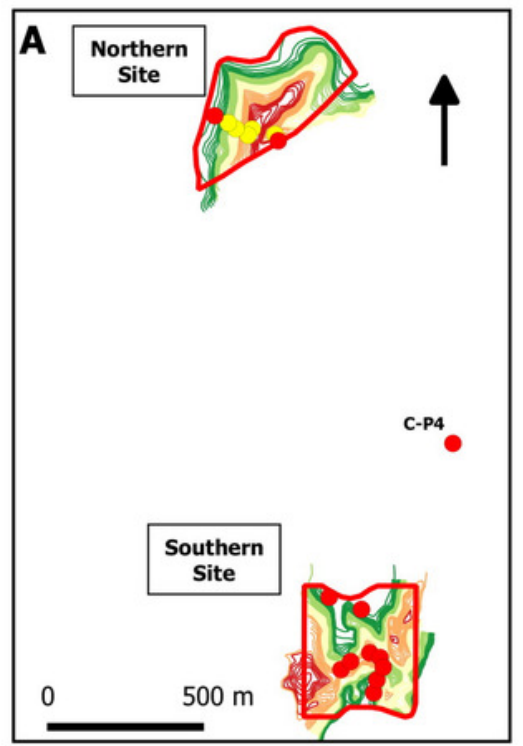

\section{Legend}

Study Site

Sampling plots

Pilot study only

B
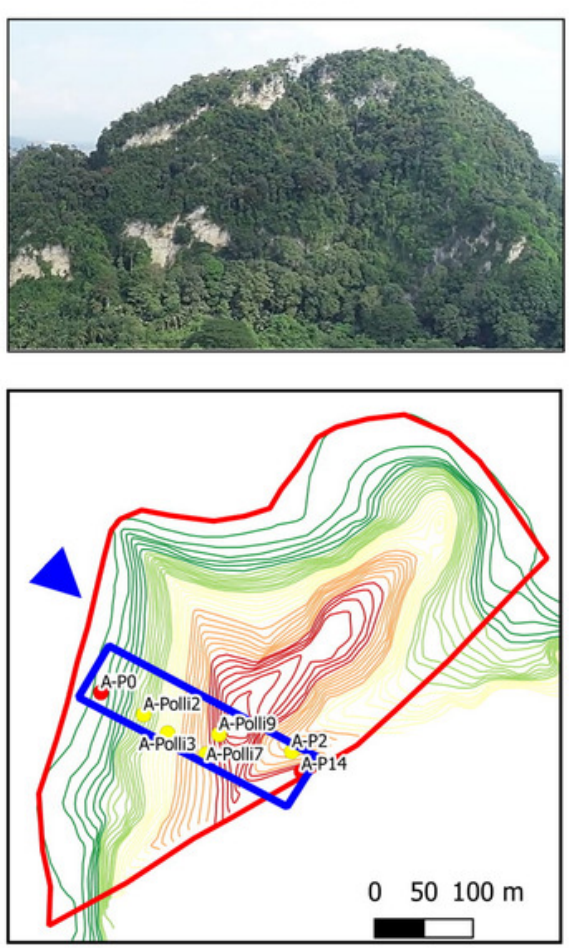

C Southern Site
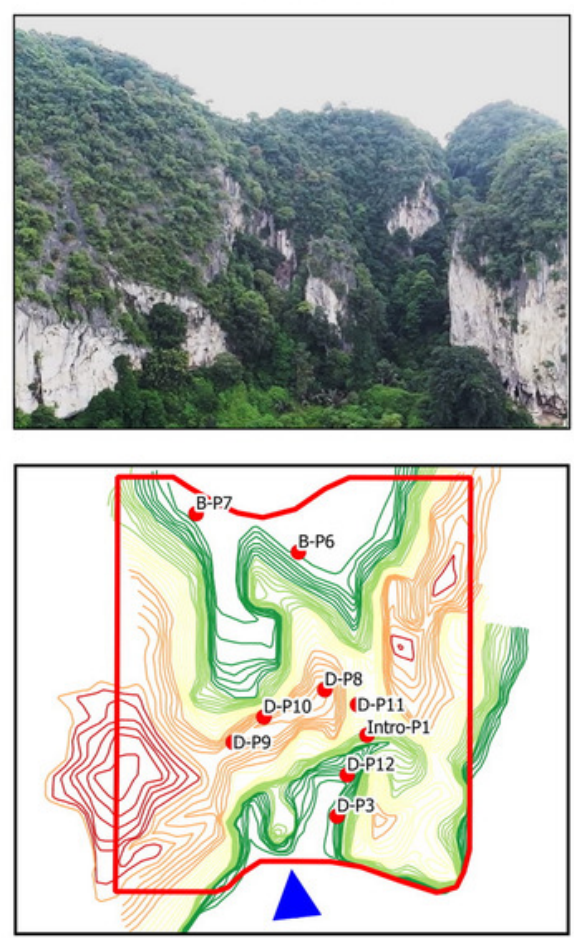

- Pilot and CMR studies

Elevation (m)

- $90-115$

$115-155$

$155-190$

$190-225$

$225-260$ 


\section{Figure 3}

Principal components analysis (PCA) plot of the first two axes for habitat, topography, and vegetation variables for the 17 plots.

The colour of the labels represents the plot location on the limestone hill and red vectors represent the habitat, topography, and vegetation variables. No individuals of Pollicaria elephas were found in plots at the southern and central part of the limestone hill, while at the northern part living snails were found in six of the seven plots (none were found in A-P14).

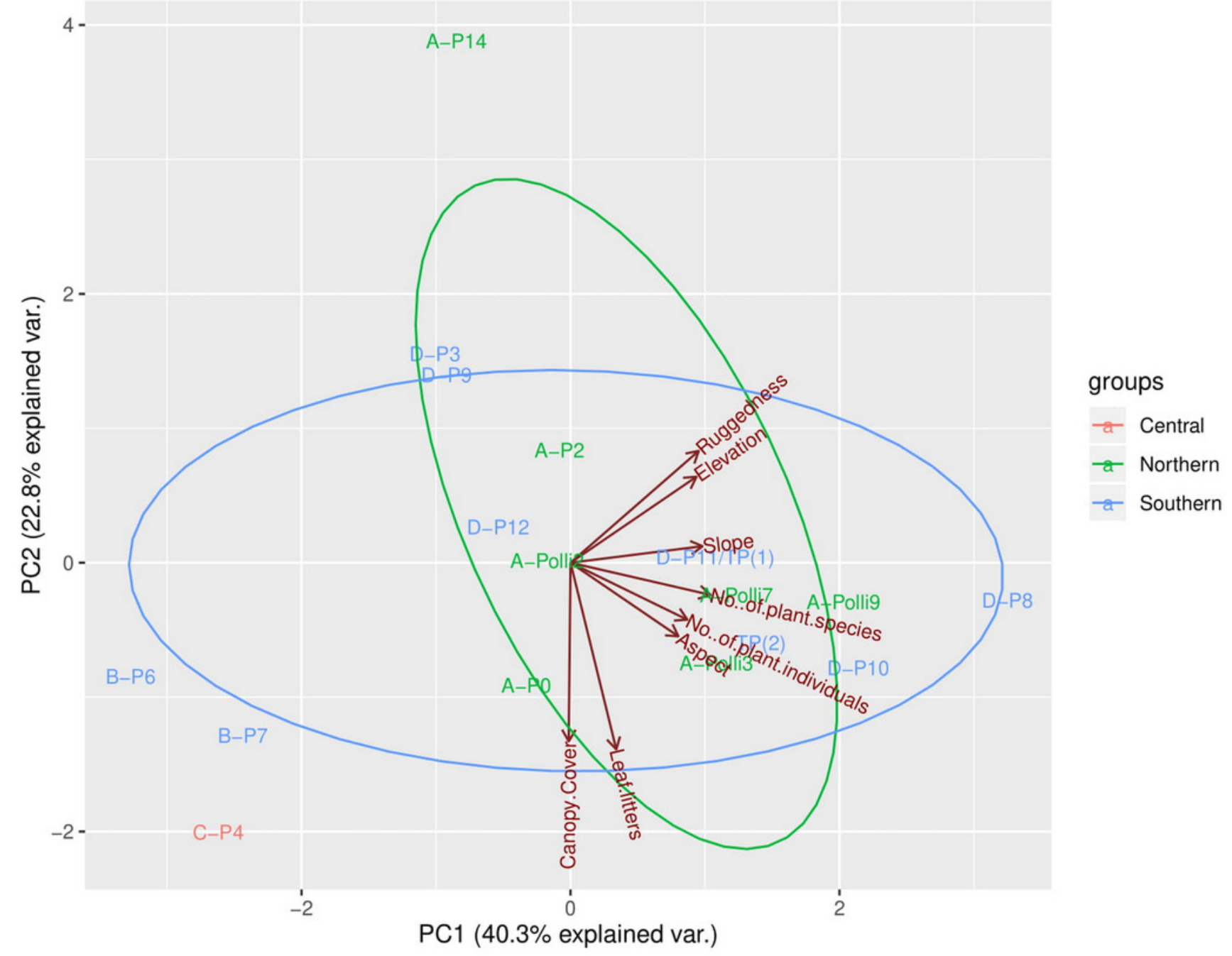


Figure 4

Soil temperature for each day in July 2018 in the six plots.

A-Polli3 and A-Polli9 are the plots with living Pollicaria elephas land snails, while the other four plots are without living $P$. elephas land snails. The insets represent the same plots with a different colour legend for the plots with living snails. (A) Mean soil temperature for each day. (B) Maximum soil temperature for each day. 


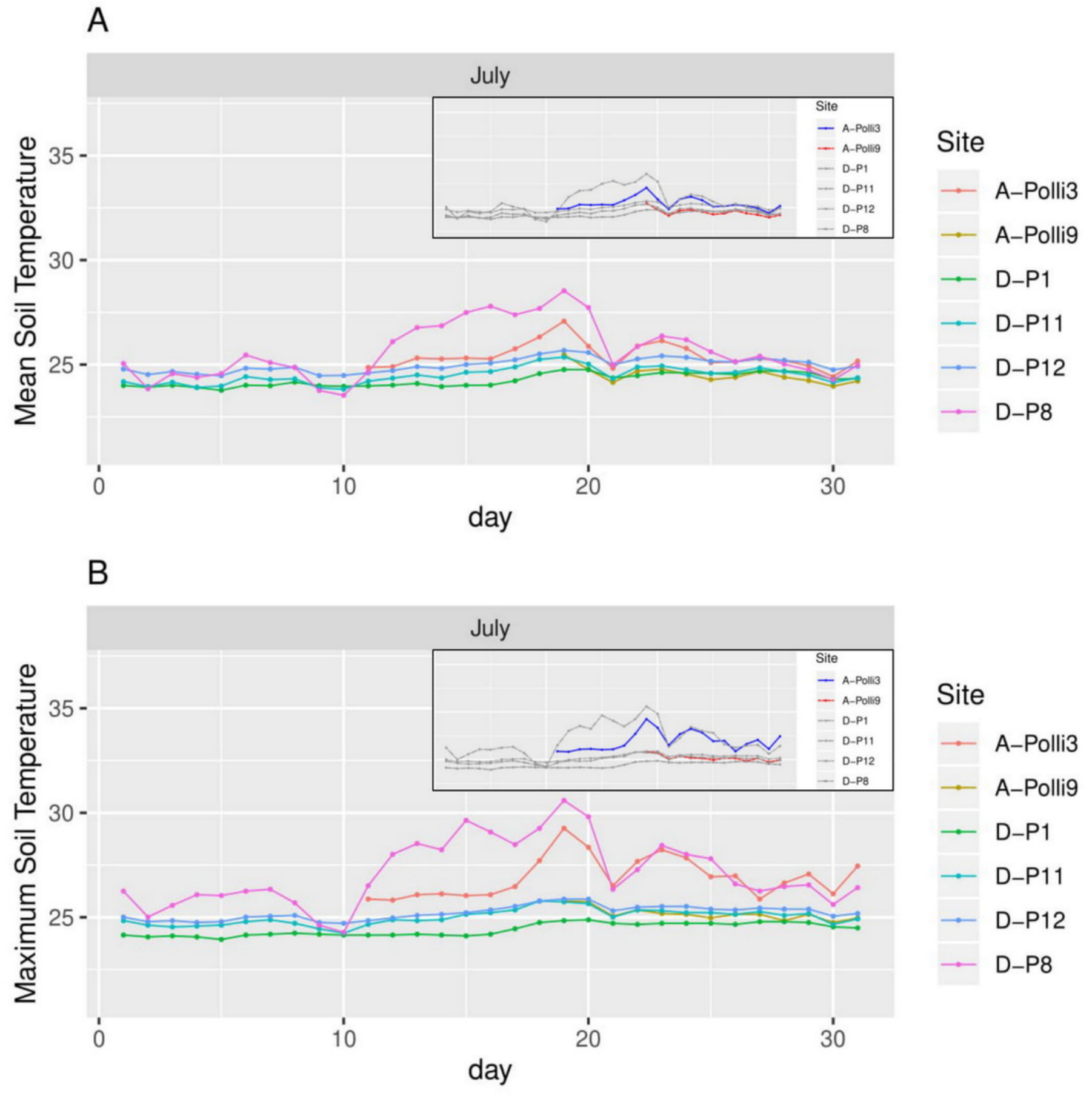




\section{Figure 5}

Air temperature for each day in July 2018 in the eight plots.

A-Polli3 and A-Polli9 are the plots with living Pollicaria elephas land snails, while the other six plots are without living $P$. elephas land snails. The insets represent the same plots with a different colour legend for the plots with living snails. (A) Mean air temperature for each day. (B) Maximum air temperature for each day. 


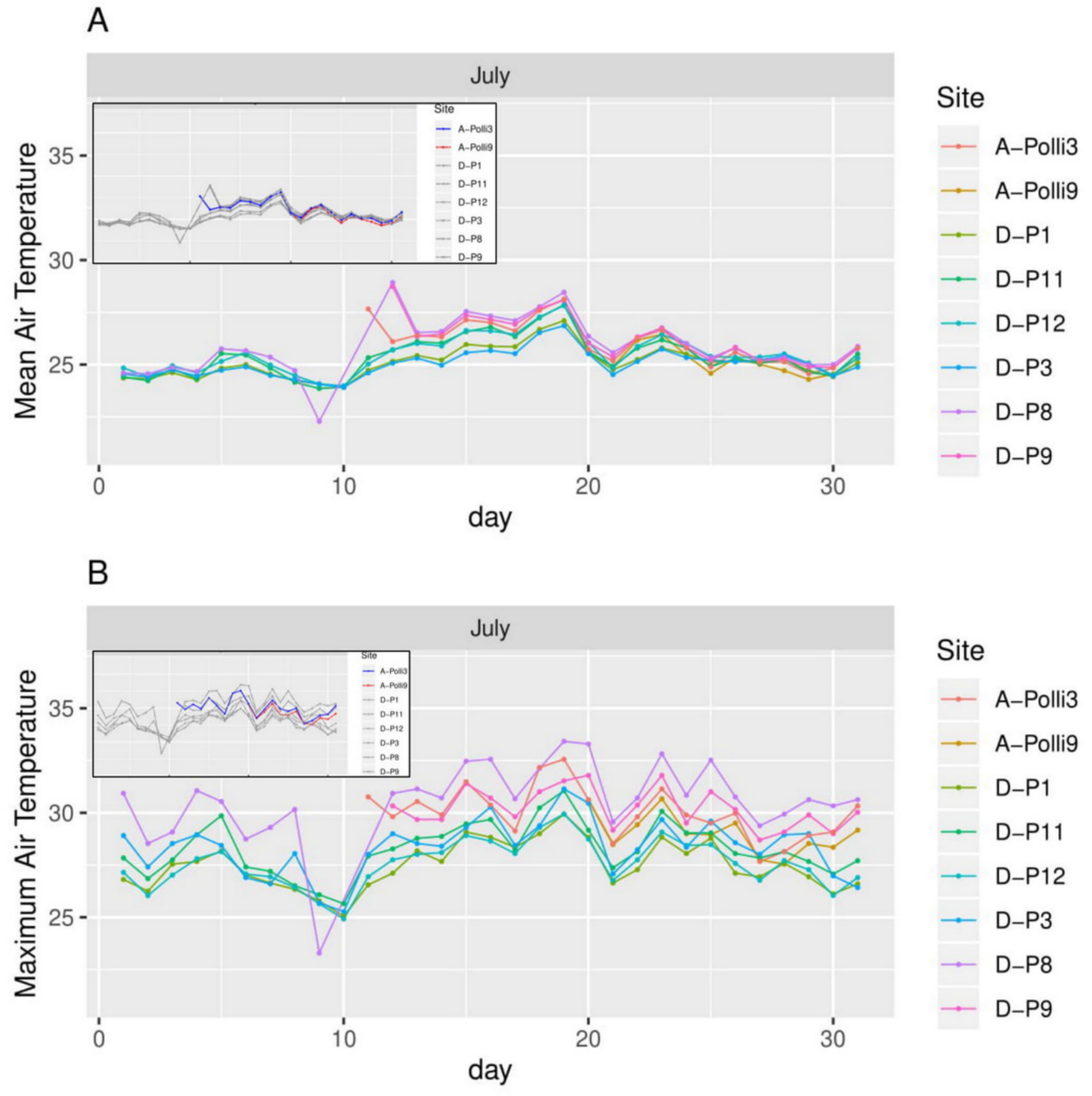




\section{Figure 6}

Humidity for each day in July 2018 in the seven plots.

Plot A-Polli3 is the plot with living Pollicaria elephas land snails, while the other six plots are without living $P$. elephas land snails. The insets represent the same plots with a different colour legend for the plots with living snails. (A) Mean humidity for each day. (B) Maximum humidity for each day. 


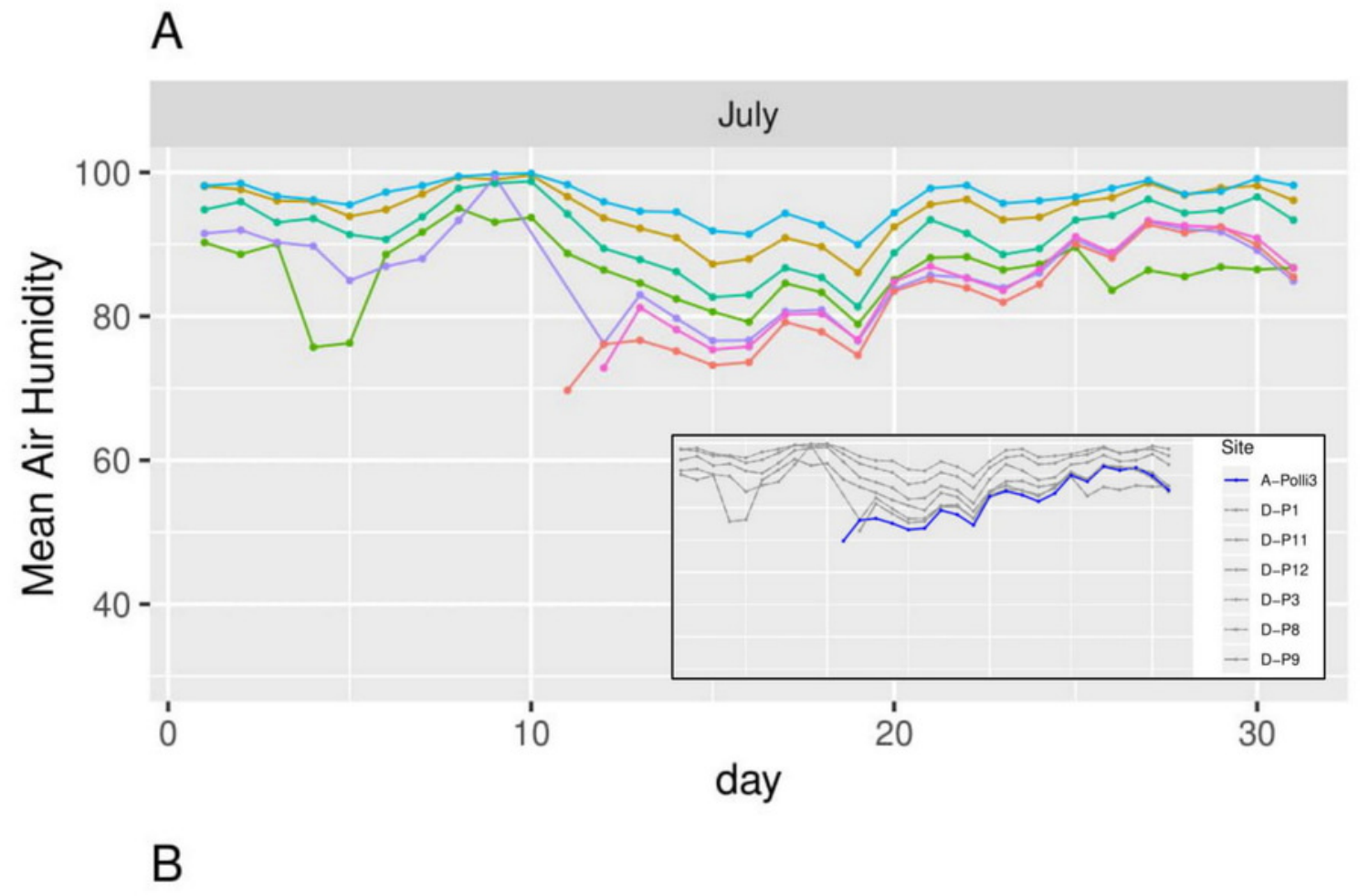

Site
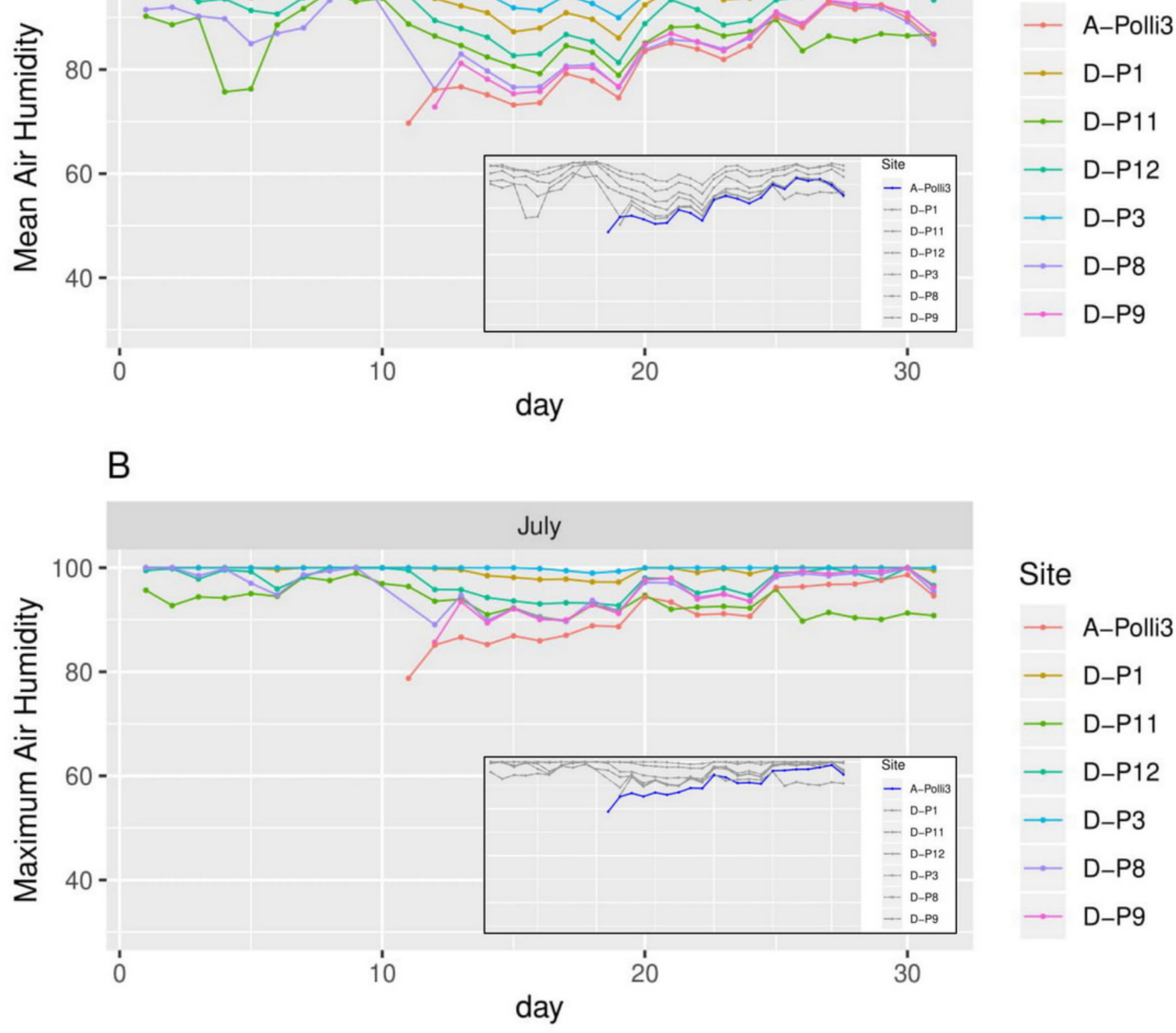

Site

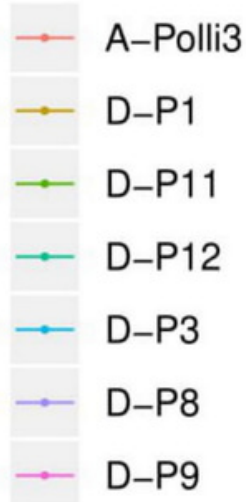

